\title{
Effect of Different Sources of Carotenoids on Growth Performance, Stress Response, and Flesh Quality in Fingerlings Grey Mullet, Liza ramada in Cultured Floating Cages \\ El-Bermawi, N. ; T. Srour; Omayma E. Shaltout and A. H. Badr EL-Din. Faculty of Agriculture (Saba Basha), Alexandria University, Egypt.
}

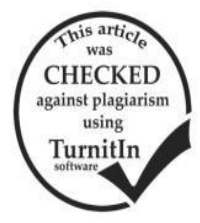

\section{ABSTRACT}

The present study was conducted to evaluate the sutability of carotenoid sources (tomato powder, $20,40 \mathrm{and} 60 \mathrm{~g} / \mathrm{kg}$; pepper powder, 30, 60 and $120 \mathrm{~g} / \mathrm{kg}$ and Synthetic Astaxanthin (vit A) at 70,75 and $80 \mathrm{mg} / \mathrm{kg}$, respectively on growth performance, stress response, feed utilization, body composition, and final flesh quality of Liza ramada. A total number of 20 Liza ramada $(4 \mathrm{~g})$ were randomly distributed into 20 hapas, and were fed daily at a rate of $5 \%$ of fish live body weight through 90 days, each treatment group was applied at two replicates. The results showed that the effect of Synthetic Astaxanthin (vit A) $(80 \mathrm{mg}$ ) was highly significant among all the other treatment in FBW, ADG, BWG, SGR, and PER. Pepper powder at 30g showed a high significant crude protein \% (58.15 \pm 0.15$)$ among all the other treatments. The TBARS values in Liza ramada flesh showed a significant decrease among all carotenoid sources as the time of frozen storage elapsed as compared to control. The effect of Paper powder at $120 \mathrm{~g}$ was highly significant from the other treatment in carotenoid flesh content while the control didn't record any deposit of carotenoids. The study demonstrated that the carotenoids sources showed significant effect on survival, growth performance, feed utilization and TBARS values.

Keywords: Liza ramada, Tomato powder, Pepper powder, Astaxanthin, growth performance, Survival, Feed utilization, carotenoids, and TBARS.

\section{INTRODUCTION}

Liza ramada is a catadromous fish with a wide distribution (Mediterranean, Black Sea, Azov Sea and Eastern Atlantic from Cape Verde and Senegal to southern Baltic and British Isles), frequently prevailing in polluted waters (Freyhof and Kottelat, 2008). Carotenoids constitute one of the most widely distributed groups of naturally occurring pigments. More than 700 different carotenoid molecules have been described and they can be found in all photosynthetic organisms, in addition to several non-photosynthetic organisms (Britton et al., 2004). The colors of these pigments range from yellow to red, and some wellknown examples are lycopene (in tomato fruit), zeaxanthin (in maize corn) and $\beta$-carotene. In photosynthetic organisms, carotenoids function as accessory light-harvesting pigments, structural components for photosystem assembly, moderators of non-photochemical quenching and as scavengers of reactive oxygen species reviewed in (Britton et al., 1999). These antioxidant properties, in addition to their color, have resulted in important industrial applications of carotenoids. In the food, feed and cosmetic industries, carotenoids such as B-carotene are widely used as dyes. In addition, studies claiming that carotenoids can prevent several human diseases (Giovannucci, 1999; Ribaya- Mercado and Blumberg, 2004 and Elliott, 2005) and are used in various nutraceutical products containing carotenoids. However, contradictory studies demonstrate no positive effect on health or even have a negative effect of carotene supplementations (Bjelakovic et al., 2007 and Kavanaugh et al., 2007). Kotkov et al. (2011) reported possible efforts to minimize negative effect of fish oil supplementation by adding antioxidant. Tomato is one of the potential natural antioxidant sources. Tomato contains some phytochemicals including lycopene, folic acid, vitamin $\mathrm{C}$, vitamin $\mathrm{A}$, vitamin $\mathrm{E}$, and phenolics which possess antioxidant activity. Hancz et al. (2003) cited that feeding diets containing paprika was reported to improve the skin pigmentation of goldfish and koi carp. Rodrigues et al. (2012) reported that astaxanthin protects membrane phospholipids and other lipids against peroxidation and was more effectively than $\beta$ carotene and lutein and shows higher scavenging capacity against peroxyl and hydroxyl radicals than that of $\alpha$-tocopherol, lutein, lycopene and $\beta$-carotene. This study aimed to investigate the effect of using carotenoid sources tomato powder, pepper powder and Astaxanthin on growth performance, chemical composition, feed utilization, and final flesh quality of Liza ramada.

\section{MATERIALS AND METHODS}

Apparently healthy one thousand fingerlings of grey mullet (Liza ramada) were obtained from a commercial fish farm in EL-Behera Governorate, Egypt. Fish were acclimated before starting the feeding experimental, and transferred to an earthen pond and reared in hapa prior to the experiment.

\section{Fish and culture conditions:}

After two-week acclimation period, fish were selected and randomly stocked into 20 hapa $(2 * 1 * 1 \mathrm{~m})$, the stocking density was 20 fish per hapa and each treatment was applied in 2 hapas. Mean initial body weight was $4 \pm 0.30 \mathrm{~g}$ for all treatments. Fish from each replicate were weighted every 2 weeks. All hapas were cleaned weekly. The pond was supplied with fresh water from Edku area. The water exchange rate was $15 \%$ of total ponds water volume/day.

\section{Basal diet and experimental design:}

Four hundred fingerlings grey mullet were randomly allocated in 20 hapas (2 hapa/ treatment) fish were subjected to the same environmental condition, and the daily amounts of food were introduced as percentage of live body weight at feeding rate of $5 \%$ for 90 days at 2 meals/day.

Preparation of the experimental diets:

The diets were prepared by mixing thoroughly the dry ingredients (Table 1) at first and with oil thereafter. The basal diet was used as a control diet without addition of carotenoids sources. Other tested 
diets were prepared by adding different levels of different sours of carotenoid, mainly tomato powder $(20,40$ and $60 \mathrm{~g} / \mathrm{kg})$, pepper powder $(30,60$ and $120 \mathrm{~g}$ $/ \mathrm{kg}$ ), and Synthetic Astaxanthin (70, 75 and $80 \mathrm{mg} /$ $\mathrm{kg}$ ), respectively. A basal diet was formulated from the commercial ingredients (fish meal, shrimp meal, soybean meal, flour, starch, vit \& min, oil and tomato , pepper powder, and Astaxanthin). The dry ingredients were grounded through a feed grinder to very small particle size $(0.5 \mathrm{~mm})$. The ingredients were weighed and mixed by a dough mixer for 20 minutes to homogeneity of the ingredients. The estimated amount of oil was gradually added (few drops) and the mixing operation was continued for minutes. After homogenous mixture was obtained, forty $\mathrm{ml}$ water per hundred $\mathrm{g}$ diet were slowly added to the mixture according to Shimeino et al. (1993). The diets were cooked on water evaporator for minutes. The diets were pelleted through fodder machine and the pellets were dried.

\section{Biological parameters:}

Mean final body weight (FBW) of each experimental treatment was determined by dividing total fish weight in each hapa by number of fish. Weight gain (WG), specific growth rate (SGR), feed conversion ratio (FCR), protein efficiency ratio (PER), protein productive value (PPV \%), energy retention (ER \%) and survival (SR \%) were calculated using the following equations according to Castell and Tiews (1980):

SGR $(\% /$ day $)=100 \times(\ln \mathrm{W} 1-\ln \mathrm{W} 0) /$ days.

$\mathrm{SR}=($ No. of fish at end / No. of fish at the start $) \times 100$.

$\mathrm{FCR}=$ dry matter feed intake $(\mathrm{g}) /$ body weight gain $(\mathrm{g})$

PER $(\%)=$ weigh gain $(\mathrm{g}) /$ protein intake $(\mathrm{g})$

PPV $(\%)=$ Retained protein $(\mathrm{g}) /$ protein intake $(\mathrm{g}) \times 100$.

Stress tolerance:

At the termination of the feeding experiment (90days), stress test has been conducted on fish to evaluate salinity (saline water ca. $35 \%$ ) effect on treated fish.

\section{Chemical analysis:}

Analysis of the experimental formulated diets and whole fish body were carried out for moisture, crude protein, ether extract, crude fiber, ash, and nitrogen free extract (NFE) according to the procedures of association of official analytical chemists (A.O.A.C, 2000) using duplicate samples.

\section{TBARS determination:}

At the end of the feeding experiment, samples of Liza ramada were put into sacks and stored frozen at $18^{\circ} \mathrm{C}$ for four months. Samples of different treatments were periodically tested on monthly bases for TBARS starting from October.

Thiobarbituric acid reactive substances (TBARS):

The Thiobarbituric acid value was determined calorimetrically by the method described by kirk and sawyer (1991) using two grey mullet flesh replicates. A portion $(200 \mathrm{mg})$ of sample was mixed with a constant volume of 1-butanol. A portion $(5.0 \mathrm{ml})$ of the mixture was pipetted into a dry stoppered test tube and $5 \mathrm{ml}$ of TBA reagent (prepared by dissolving $200 \mathrm{mg}$ of 2-TBA in $100 \mathrm{ml} 1$-butanol, filtered, stored at $4^{\circ} \mathrm{C}$ for not more than 7 days) were added. The test tubes were stoppered, vortexed and placed in a water bath at $95^{\circ} \mathrm{C}$ for 120 min, then cooled. Absorbance (As) was measured at 530 $\mathrm{nm}$ against water blank. A reagent blank was run and absorbance (Ab) recorded. Using spectrophotometer (T80 UV/VIS Spectrometer PG instruments Ltd) for estimating absorbance of grey mullet flesh samples. TBA value ( $\mathrm{mg}$ of malonaldehyde) equivalents/ $\mathrm{kg}$ of tissue) was obtained by the formula: TBA $=50 \mathrm{x}$ (AsAb) / 200

\section{Statistical analysis:}

The data collected were statistically analyzed using General Linear Models Procedure (GLM) adapted by SPSS (1997) for users guide. Means were statistically compared for the significance $(\mathrm{P}<0.05)$ using Duncan'smultiple range test (1955).

Table 1. Shows the feed ingredients and chemical composition of the basal diet:

\begin{tabular}{|c|c|c|c|c|c|c|c|c|c|c|}
\hline Ingredients composition & T1 & T2 & T3 & T4 & T5 & T6 & T7 & T8 & T9 & T10 \\
\hline Fish meal & 25 & 25 & 25 & 25 & 25 & 25 & 25 & 25 & 25 & 25 \\
\hline Shrimp meal & 18 & 18 & 18 & 18 & 18 & 18 & 18 & 18 & 18 & 18 \\
\hline Soybean & 27 & 27 & 27 & 27 & 27 & 27 & 27 & 27 & 27 & 27 \\
\hline Corn flour & 23 & 21 & 19 & 17 & 20 & 17 & 11 & 23 & 23 & 23 \\
\hline Starch & 6 & 6 & 6 & 6 & 6 & 6 & 6 & 6 & 6 & 6 \\
\hline Vitamin and minerals mixture* & 0.3 & 0.3 & 0.3 & 0.3 & 0.3 & 0.3 & 0.3 & 0.3 & 0.3 & 0.3 \\
\hline Corn oil & 0.7 & 0.7 & 0.7 & 0.7 & 0.7 & 0.7 & 0.7 & 0.7 & 0.7 & 0.7 \\
\hline Tomato & - & 2 & 4 & 6 & - & - & - & - & - & - \\
\hline Pepper & - & - & - & - & 3 & 6 & 12 & - & - & - \\
\hline Astaxanthin & - & - & - & - & - & - & - & 70 & 75 & 80 \\
\hline \multicolumn{11}{|l|}{ Chemical composition } \\
\hline Dry matter (DM) & 92.43 & 91.83 & 92.58 & 90.18 & 92.8 & 92.88 & 95.22 & 89.73 & 95.74 & 89.61 \\
\hline Crude protein $(\mathrm{CP})$ & 39.45 & 39.10 & 39.15 & 39.40 & 39.15 & 39.60 & 38.80 & 39.30 & 39,30 & 39.20 \\
\hline Ether extract(EE) & 5.37 & 5.42 & 4.33 & 4.33 & 4.33 & 5.22 & 5.67 & 5.42 & 4.78 & 5.31 \\
\hline Ash & 10.31 & 10.85 & 9.69 & 11.19 & 11.19 & 10.83 & 9.20 & 9.72 & 11.54 & 8.93 \\
\hline Crude fiber $(\mathrm{CF})$ & 2.78 & 3.05 & 2.70 & 2.76 & 2.89 & 2.73 & 2.95 & 2.75 & 2.83 & 2.88 \\
\hline Nitrogen free extract (NFE) & 42.09 & 44.85 & 44.13 & 42.32 & 42.44 & 41.62 & 43.38 & 42.81 & 41.55 & 43.68 \\
\hline Gross energy** (Kcal/100gm) & 446.22 & 442.62 & 443.06 & 437.04 & 436.15 & 443.67 & 450.62 & 448.81 & 437.57 & 450.73 \\
\hline $\mathrm{N}: \mathrm{C}$ ratio $\mathrm{mg} \mathrm{CP}$ : Kcal GE & 88.41 & 88.34 & 88.36 & 90.19 & 89.78 & 89.26 & 86.11 & 87.57 & 89.81 & 86.97 \\
\hline
\end{tabular}

\footnotetext{
T1 : control; T2,T3,T4: Tomato 20-40-60 g/Kg; T5,T6,T7 : Pepper 30-60-120g/Kg),T8,T9,T10 Astaxanthin 70-75-80mg/Kg) add by mg.

*Premix Composition:- Each 3 kg contains Vit A 1200000 i.u., Vit D 300000 i.u., Vit E $700 \mathrm{mg}$, Vit K3 $500 \mathrm{mg}$, Vit B1 $500 \mathrm{mg}$, Vit B2 $200 \mathrm{mg}$, Vit B6 600mg, Vit B12 3mg, Vit C 450mg, Niacin 3000mg, Methionine3000mg, Cholin chloride 10000mg, Folic acid 300mg, Biotin 6mg, Panthonic acid 670mg, Magnesiam salphate 3000mg, Copper sulphate $3000 \mathrm{mg}$, Iron sulphate $1000 \mathrm{mg}$, Zinc sulphate, 1800mg, Cobalt sulphate 300mg, Carrier upto 3000mg.
} **Gross energy, calculated on the basis of 5.64, 4, 11 and 9, 44 kcal GE / g protein, NFE and Ether Extract respectively (NRC, 1993). 


\section{RESULTS AND DISCUSSION}

\section{Growth performance and feed utilization:}

Growth performance and feed utilization of Liza ramada fingerlings has been studied for 90 days and presented in Tables 2 and 3. There were no significant differences in initial body weight among all tested treatment. Which mean that a random distribution of fish was performed in the different treatments at the beginning of the experiment. During the period of the study data indicated that among all the tested treatments Astaxanthin $80 \mathrm{mg} / \mathrm{Kg}$ diet has been improved FBW, ADG, BWG, and SGR significantly (25.30 \pm 0.30 , $0.24 \pm 0.00,21.14 \pm 0.31,2.01 \pm 0.02$, respectively).

Table 2. Effect of different dietary carotenoids sources on final body weight (FBW), body weight gain (BWG), specific growth rate (SGR) and survival rate (\%) for Liza ramadas fingerlings (mean \pm S.E.).

\begin{tabular}{|c|c|c|c|c|c|c|}
\hline Items & Initial W & Final W & Weight Gain & ADG & SGR & Survival \\
\hline $\mathrm{T} 1$ & $4.19 \pm 0.02$ & $13.19 \pm 0.04^{\mathrm{g}}$ & $9.01 \pm 0.03^{g}$ & $0.10 \pm 0.00 \mathrm{f}^{\mathrm{g}}$ & $1.28 \pm 0.00^{\mathrm{gh}}$ & $92.50 \pm 2.50$ \\
\hline $\mathrm{T} 2$ & $4.16 \pm 0.00$ & $13.63 \pm 0.09^{\mathrm{fg}}$ & $9.48 \pm 0.08^{\mathrm{fg}}$ & $0.11 \pm 0.01^{\text {efg }}$ & $1.33 \pm 0.01 \mathrm{f}^{\mathrm{g}}$ & $92.50 \pm 7.50$ \\
\hline $\mathrm{T} 3$ & $4.21 \pm 0.01$ & $15.15 \pm 0.14^{\mathrm{d}}$ & $10.95 \pm 0.12^{\mathrm{d}}$ & $0.12 \pm 0.00^{\mathrm{d}}$ & $1.43 \pm 0.01^{\mathrm{d}}$ & $85.00 \pm 5.00$ \\
\hline $\mathrm{T} 4$ & $4.21 \pm 0.00$ & $14.53 \pm 0.33^{\mathrm{def}}$ & $10.33 \pm 0.32^{\mathrm{def}}$ & $0.12 \pm 0.01^{\mathrm{de}}$ & $1.38 \pm 0.02^{\mathrm{def}}$ & $100.00 \pm 0.00$ \\
\hline $\mathrm{T} 5$ & $4.17 \pm 0.01$ & $14.85 \pm 0.21^{\mathrm{de}}$ & $10.68 \pm 0.22^{\mathrm{de}}$ & $0.12 \pm 0.00^{\mathrm{d}}$ & $1.41 \pm 0.02^{\mathrm{de}}$ & $90.00 \pm 0.00$ \\
\hline T6 & $4.19 \pm 0.02$ & $13.96 \pm 0.21^{\mathrm{efg}}$ & $9.77 \pm 0.22^{\text {efg }}$ & $0.11 \pm 0.00^{\mathrm{def}}$ & $1.34 \pm 0.02^{\mathrm{efg}}$ & $90.00 \pm 0.00$ \\
\hline $\mathrm{T} 7$ & $4.21 \pm 0.01$ & $12.97 \pm 0.45^{\mathrm{g}}$ & $8.76 \pm 0.46^{\mathrm{g}}$ & $0.10 \pm 0.01^{\mathrm{g}}$ & $1.25 \pm 0.04^{\mathrm{h}}$ & $100.00 \pm 0.00$ \\
\hline $\mathrm{T} 8$ & $4.23 \pm 0.00$ & $16.67 \pm 0.53^{c}$ & $12.44 \pm 0.53^{c}$ & $0.14 \pm 0.01^{\mathrm{c}}$ & $1.53 \pm 0.04^{\mathrm{c}}$ & $92.50 \pm 7.50$ \\
\hline T9 & $4.18 \pm 0.00$ & $22.93 \pm 0.32^{\mathrm{b}}$ & $18.75 \pm 0.32^{b}$ & $0.21 \pm 0.00^{\mathrm{b}}$ & $1.90 \pm 0.02^{\mathrm{b}}$ & $95.00 \pm 5.00$ \\
\hline $\mathrm{T} 10$ & $4.17 \pm 0.01$ & $25.30 \pm 0.30^{\mathrm{a}}$ & $21.14 \pm 0.31^{\mathrm{a}}$ & $0.24 \pm 0.00^{\mathrm{a}}$ & $2.01 \pm 0.02^{\mathrm{a}}$ & $92.50 \pm 7.50$ \\
\hline
\end{tabular}

a,b,c,d,e,f, and g means in the same column with different letters differ significantly at 0.05 level .

T1 : control (T2,T3,T4: Tomato 20-40-60 g/Kg), (T5,T6,T7 : Pepper 30-60-120g/Kg),T8,T9,T10 Astaxanthin 70-75-80mg/Kg).

Data of growth parameters and feed utilization of Liza ramada summarized in Tables 2 and 3 showed that the response of fish to different levels of tomato, pepper, and astaxanthin in diet is different. Data show that all fish fed different carotenoid sources diet resulted in higher growth performance than the control diet, suggesting that the addition of carotenoid (Astaxanthin $80 \mathrm{mg} / \mathrm{Kg}$ ) to the diets enhanced the growth performance and survival (\%) of Liza ramada which gave the highest values of final body weight (FBW), weight gain (WG), specific growth rate (SGR) and survival (\%) while the lowest values was observed for fish fed the control diet. The same trend was observed for PER, PPV (\%), ER (\%) and the best FCR vales. These results are in partial agreement with the results of Maeda et al. (2013) and Sajjad et al. (2013), who reported the effect of placement carrot and red pepper on growth, pigmentation and blood factors of rainbow trout and grey mullet. The results showed a significant difference between treatments in terms of weight and length $(\mathrm{P}<0.05)$ and no significant differences $(\mathrm{P}>0.05)$ in food intake and growth performance parameters. The successful use of Liza ramada (Strati and Oreopoulou, 2014) of carotenoids from tomato processing byproducts indicated that tomato waste should be regarded as potential nutraceutic resource and may be used as a functional food ingredient. Plant carotenoids can be stated with greater accumulation in the tissues, due to its vitamins, carotene, and immersed color (Amaninejad, 2009 and Faghani et al., 2009) has been reported for Liza ramada feeding. Carotenoids in dry tomato byproduct and pepper have positive effect on growth rate and survival rate may be due to well credited with important health promoting functions, such as provitamin A and antioxidant activity enhancement of the immune system and reduction of the degenerative diseases such as cancer (Wang et al., 2006 and Hernandez et al., 2007). Kalinowsky et al. (2005) found that carotenoids have appositive effect on growth performance of pagers. A similar study by $\mathrm{Hu}$ et al. (2006) on young hybrid tilapia, was indicative of the fact that dietary $\beta$ - carotene resulted in an increase in growth performance of the fish. These results are in partial agreement with the findings of Yew-hu and Wen (2005) and Strati and Oreopoulou (2014) who reported that the control diet and diet containing dried tomato, pepper $(60 \mathrm{Mg} / \mathrm{Kg})$ and astaxanthin, all being a rich source of natural carotenoids and astxanthin levels (50.and $100 \mathrm{Mg} / \mathrm{Kg}$ ) fed to Liza ramada produced significantly higher PER, FCR and PPV values compared to diets (control) without tomato, pepper and Astaxathin.

Table 3. Effect of dietary carotenoids on feed intake, feed conversion ratio (FCR), protein utilization (PERPPV), energy gain and utilization for Liza ramada fingerlings.

\begin{tabular}{|c|c|c|c|c|c|c|}
\hline Items & Feed intake & FCR & PER & PPV & Energy Gain & Energy U \\
\hline $\mathrm{T} 1$ & $36.31 \pm 0.16^{\mathrm{d}}$ & $3.84 \pm 0.02^{b}$ & $0.66 \pm 0.01 f^{g}$ & $12.98 \pm 0.16 \mathrm{~d}^{\mathrm{e}}$ & $16.33 \pm 0.26^{\mathrm{d}}$ & $10.52 \pm 0.25^{\mathrm{c}}$ \\
\hline $\mathrm{T} 2$ & $35.31 \pm 0.06^{c}$ & $3.23 \pm 0.02^{b c}$ & $0.67 \pm 0.01^{\mathrm{fg}}$ & $12.05 \pm 0.11^{\mathrm{e}}$ & $16.56 \pm 0.22^{\mathrm{d}}$ & $10.31 \pm 0.03^{c}$ \\
\hline $\mathrm{T} 3$ & $36.65 \pm 0.07^{\mathrm{cd}}$ & $3.56 \pm 0.11^{\mathrm{ef}}$ & $0.79 \pm 0.00^{\mathrm{cd}}$ & $15.01 \pm 0.07^{\mathrm{cd}}$ & $19.53 \pm 0.41^{\mathrm{cd}}$ & $12.49 \pm 0.23^{b c}$ \\
\hline $\mathrm{T} 4$ & $36.58 \pm 0.16^{\mathrm{bc}}$ & $3.53 \pm 0.05^{\mathrm{cd}}$ & $0.72 \pm 0.02^{\mathrm{ef}}$ & $12.90 \pm 1.05^{\mathrm{de}}$ & $18.39 \pm 1.27^{\mathrm{cd}}$ & $11.50 \pm 0.99^{c}$ \\
\hline T5 & $34.87 \pm 1.04^{\mathrm{bc}}$ & $3.57 \pm 0.03^{\mathrm{de}}$ & $0.75 \pm 0.02^{\mathrm{de}}$ & $14.29 \pm 0.26^{\mathrm{ced}}$ & $18.10 \pm 0.49^{\mathrm{cd}}$ & $11.35 \pm 0.53^{\mathrm{c}}$ \\
\hline T6 & $36.78 \pm 0.35^{\mathrm{d}}$ & $4.21 \pm 0.18^{\mathrm{cd}}$ & $0.71 \pm 0.00^{\mathrm{ef}}$ & $14.11 \pm 0.37^{\mathrm{ced}}$ & $17.52 \pm 1.12 c^{d}$ & $11.32 \pm 0.49^{c}$ \\
\hline $\mathrm{T} 7$ & $38.01 \pm 0.34^{\mathrm{bc}}$ & $3.06 \pm 0.16^{\mathrm{a}}$ & $0.62 \pm 0.03^{\mathrm{g}}$ & $13.41 \pm 2.12^{\text {ced }}$ & $16.87 \pm 2.57^{\mathrm{d}}$ & $10.18 \pm 1.55^{\mathrm{c}}$ \\
\hline $\mathrm{T} 8$ & $51.37 \pm 0.07^{\mathrm{b}}$ & $2.74 \pm 0.04^{\mathrm{f}}$ & $0.83 \pm 0.04^{c}$ & $16.16 \pm 0.94^{\mathrm{bc}}$ & $21.41 \pm 0.89^{c}$ & $12.56 \pm 0.72^{\mathrm{bc}}$ \\
\hline T9 & $50.54 \pm 0.58^{\mathrm{a}}$ & $2.39 \pm 0.01^{\mathrm{g}}$ & $0.93 \pm 0.03^{b}$ & $18.01 \pm 0.01^{\mathrm{ab}}$ & $33.21 \pm 1.43^{\mathrm{b}}$ & $14.77 \pm 0.64^{\mathrm{ab}}$ \\
\hline $\mathrm{T} 10$ & $34.82 \pm 0.58^{\mathrm{a}}$ & $3.39 \pm 0.03^{\mathrm{h}}$ & $1.07 \pm 0.01^{\mathrm{a}}$ & $19.83 \pm 0.25^{\mathrm{a}}$ & $38.28 \pm 0.74^{\mathrm{a}}$ & $16.80 \pm 0.13^{\mathrm{a}}$ \\
\hline
\end{tabular}


Results of this experiment conducted with studies on trout fingerling with plant carotenoids (Mehrobi et al., 2008). Carotenoids in salmon fishes (Bjerkeng et al., 2000) were similar, but studies on shrimp and trout fed with red pepper (Harpaz et al., 2000 and Yanar et al., 2007) this positive effects on feed efficiency may be due to tomato, pepper waste extracts contained considerable amounts of carotenoids (lycopene and $\beta$ carotene), and exhibit good antioxidant and anti proliferation activities. Therefore, because of their low costs and bio- renewable nature, tomato waste could be alternative source of valuable bioactive compounds. Maede et al. (2013) showed that the use of vegetable ingredients in diets for rainbow trout is an effective and affordable and the diet of $55 \mathrm{mg} / \mathrm{Kg}$ red bell pepper is available diet for rearing rainbow trout.

The data illustrated in Table 4 showed the effects of deferent (carotenoids) on carcass composition and gross energy of Liza ramada fingerlings. The results indicated significant $(\mathrm{P}<0.05)$ differences among the body percentage of crude protein $(\mathrm{CP})$, ether extract (EE), ash and carcass energy. Meanwhile, the treatment fed with diet pepper $(6 \%)$ increased $\mathrm{CP} \%$ and decreased the value of EE and carcass energy. As for dry matter, there were no significant differences among the treatments. As the concentration of (crude protein, CP) increased in the diet, the carcass water content was reduced. The lowest fat and highest ash contents were recorded in the fish fed the $20 \% \mathrm{CP}$ diet. Furthermore, Richter et al. (2003) and Abdelhamid et al. (2004) studied the effect of dried moringa leaf meal and water hyacinth inclusion level (20 and 30\%) as alternative protein source for Nile tilapia on body chemical composition. They reported that increasing the level of moringa leaves in the diet increased moisture body, while lipid and gross energy values decreased significantly $(\mathrm{p}<0.05)$. Crude protein and crude ash contents remained constant in all experimental groups.

Table 4. Effect of different carotenoids sources on carcass composition for Liza ramada fingerlings.

\begin{tabular}{|c|c|c|c|c|c|}
\hline \multirow{2}{*}{ Items } & \multirow{2}{*}{ Dry matter } & \multicolumn{3}{|c|}{$\%$ on dry matter basis } & \multirow{2}{*}{$\begin{array}{l}\text { Carcass } \\
\text { energy }\end{array}$} \\
\hline & & Protein & Ether extract & Ash & \\
\hline $\mathrm{T} 1$ & $29.81 \pm 0.27$ & $56.02 \pm 0.38^{\mathrm{bc}}$ & $25.10 \pm 0.08^{\mathrm{a}}$ & $18.89 \pm 0.47$ & $552.85 \pm 2.95^{\mathrm{a}}$ \\
\hline $\mathrm{T} 2$ & $30.73 \pm 0.23$ & $56.85 \pm 0.15^{\mathrm{ab}}$ & $24.07 \pm 0.81^{\mathrm{ab}}$ & $19.09 \pm 0.96$ & $\pm 8.44^{\mathrm{ab}}$ \\
\hline $\mathrm{T} 3$ & $30.70 \pm 1.15$ & $54.55 \pm 0.35^{\mathrm{c}}$ & $25.24 \pm 0.64^{\mathrm{a}}$ & $20.21 \pm 0.29$ & $545.93 \pm 4.07^{\mathrm{ab}}$ \\
\hline $\mathrm{T} 4$ & $30.41 \pm 0.80$ & $57.90 \pm 0.10^{\mathrm{a}}$ & $21.77 \pm 0.57^{\mathrm{c}}$ & $20.33 \pm 0.47$ & 532.0 \\
\hline $\mathrm{T} 5$ & $31.03 \pm 0.76$ & $58.15 \pm 0.15^{\mathrm{a}}$ & $22.62 \pm 0.52^{\mathrm{bc}}$ & $19.23 \pm$ & 541 \\
\hline T6 & $33.05 \pm 2.70$ & $57.80 \pm 0.60^{\mathrm{a}}$ & $21.80 \pm 0.60^{\mathrm{c}}$ & $20.40 \pm 0.01$ & $531.78 \pm 2.28^{\mathrm{b}}$ \\
\hline $\mathrm{T} 7$ & $30.90 \pm 0.25$ & $58.00 \pm 0.10^{\mathrm{a}}$ & $21.74 \pm 0.46^{\mathrm{c}}$ & $20.26 \pm 0.36$ & $532.35 \pm 3.77^{\mathrm{b}}$ \\
\hline $\mathrm{T} 8$ & $31.61 \pm 1.23$ & $58.06 \pm 0.64^{\mathrm{a}}$ & $22.55 \pm 1.05^{\mathrm{bc}}$ & $19.39 \pm 0.41$ & $540.33 \pm 6.30^{\mathrm{ab}}$ \\
\hline T9 & $31.73 \pm 0.08$ & $56.00 \pm 0.10^{\mathrm{bc}}$ & $24.87 \pm 0.47^{\mathrm{a}}$ & $19.14 \pm 0.37$ & $550.57 \pm 3.82^{\mathrm{a}}$ \\
\hline $\mathrm{T} 10$ & $31.12 \pm 0$ & $57.31 \pm 1.11^{\mathrm{ab}}$ & $23.25 \pm 0.45^{\mathrm{abc}}$ & $19.44 \pm 0$. & $542.71 \pm 2.01^{\mathrm{ab}}$ \\
\hline
\end{tabular}

a,b,c,d,e,f, and $\mathrm{g}$ means in the same column different letters differ significantly at 0.05 level .

T1 : control (T2,T3,T4: Tomato 20-40-60 g/Kg), (T5,T6,T7 : Paper 30-60-120g/Kg),T8,T9,T10 Astaxanthin 70-75-80mg/Kg.

\section{The effect of salinity of Liza ramada:}

During stress period, survival of control group was very high under salinity stress condition compared with all diets containing $\beta$-carotene supplemented diets. Pepper supplemented diet $(120 \mathrm{~g} / \mathrm{kg})$ at time 34.15 hours followed by that containing tomato and astaxanthin compared with the control. The effects of dietary supplementation of carotenoids (tomato, and pepper) and astaxanthin on low and high salinity stress resistance (Table 5) when subjected to change salinity stress Liza ramada fed dietary supplementation of carotenoids. These results agree with those of Yen-hu and Wen (2005) and similar results were reported by Chien et al. (1999) on juvenile fed with diet without astaxanthin supplement compared with those fed with $360 \mathrm{mg} / \mathrm{kg}$ astaxanthin for one week.

Table 5. The effect of dietary supplementation of tomato, pepper, and astaxanthin on salinity (35 $\mathrm{mg}$ /) stress resistance of Liza ramada.

\begin{tabular}{lcccccccccc}
\hline $\begin{array}{l}\text { No of } \\
\text { dead fish }\end{array}$ & T1 & T2 & T3 & T4 & T5 & T6 & T7 & T8 & T9 & T10 \\
\hline 1 & 3.13 & 2.08 & 2.70 & 2.40 & 7.15 & 6.15 & 29.20 & 4.20 & 3.13 & 5.13 \\
2 & 3.10 & 2.18 & 3.80 & 3.22 & 9.28 & 7.25 & 32.55 & 4.40 & 3.15 & 5.15 \\
3 & 3.28 & 2.55 & 4.05 & 4.15 & 12.35 & 8.20 & 35.15 & 5.15 & 3.38 & 5.43 \\
4 & 3.45 & 3.13 & 6.05 & 4.35 & 13.189 .15 & 35.48 & 5.43 & 4.38 & 6.23 \\
5 & 3.75 & 3.18 & 6.25 & 5.05 & 13.489 .15 & 36.28 & 6.20 & 5.15 & 6.35
\end{tabular}

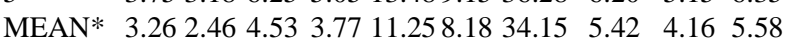

*Average number of hours incurred by fish of high salinity .

T1 : control (T2,T3,T4: Tomato 20-40-60 g/Kg), (T5,T6,T7 : Paper 30-60-120g/Kg),T8,T9,T10 Astaxanthin 70-75-80mg/Kg)

\section{The effect of storage on the quality of fish flesh:}

The TBA reactive substance is a test which indicates the oxidative changes in muscle foods during storage (Egan et al., 1981). Thiobarbituric acid reactive substance (TBARS) is widely used as indicator for the assessment of the degree of lipid oxidation (Jeon et al., 2002). In the present study (Table 6) the TBA values of the different treatment recorded a steady rise throughout the storage period $\left(3\right.$ months at $\left.-18^{\circ} \mathrm{C}\right)$. As a matter of fact, the feed containing tomato powder treatment at 20 and 40\% (T1 and T2) exhibited a significant decrease in TBA value of flesh being 5.41 and 5.09, mg melanodialdehyde / $\mathrm{kg}$ tissue as compared to the T3 treatment and control which reached 7.63 and 6.33 melanodialdehyde / $\mathrm{kg}$ tissue at the end of the storage period, respectively. On the other hand, the feed containing $30 \mathrm{~g} / \mathrm{kg}$ (T4) paprika recorded the best TBA value at the end of the frozen storage period being 5.16 $\mathrm{mg}$ malondialdehyde $/ \mathrm{kg}$ tissue, whereas the TBA value of $\mathrm{T} 5$ and $\mathrm{T} 6$ reached 7.82 and $10.00 \mathrm{mg}$ malondialdehyde $/ \mathrm{kg}$ tissue at the end of the storage period even though higher than the control samples. It is well documented that the high concentration of natural antioxidants may exhibit an attenuating effect or a pro oxidant effect (Aruoma et al., 1992). On contrary to the aforementioned results, the synthetic vitamin (A) recorded a significant decrease $(\mathrm{p}<0.05)$ in TBA value of the fish tissue which was more pronounced at the higher levels used (T8 and T9) being 4.38 and $4.61 \mathrm{mg}$ melanodialdehyde $/ \mathrm{kg}$ tissue as compared to the control (6.33) and all the other treatments at the end of the storage period. It may be concluded that tomato powder at $\mathrm{T} 1$ and $\mathrm{T} 2$ addition and paprika at $\mathrm{T} 4$ addition achieved significant potential in lowering the onset of lipid oxidation as compared to synthetic vitamin A and control samples. Notwithstanding, it was reported that the maximum level of TBARS value indicating good 
quality of fish tissue frozen, chilled or stored in ice is 3$5 \mathrm{mg}$ melanodialdehyde/ kg Tissue (Egan et al., 1981).

Table 6. the Effect of different concentrations of plant ingredients and vitamin(A)on thiobarbituric acid reactive substances (TBARS) of grey mullet flash during frozen storage at $-18^{\circ} \mathrm{C}$.

\begin{tabular}{lcccc}
\hline \multirow{2}{*}{ Treatment } & \multicolumn{4}{c}{ Storage time (months) } \\
\cline { 2 - 3 } Tomato powder & 1 month & 2 month & 3 month \\
T2 & $4.50 \pm 0.05^{\mathrm{bc}}$ & $4.67 \pm 0.05^{\mathrm{bc}}$ & $5.11 \pm 0.33^{\mathrm{bcd}}$ & $5.41 \pm 0.39^{\mathrm{cd}}$ \\
T4 & $4.22 \pm 0.33^{\mathrm{bc}}$ & $4.46 \pm 0.36^{\mathrm{bc}}$ & $4.82 \pm 0.27^{\mathrm{cd}}$ & $5.09 \pm 0.28^{\mathrm{cd}}$ \\
T6 & $6.11 \pm 0.63^{\mathrm{ab}}$ & $6.28 \pm 0.66^{\mathrm{ab}}$ & $7.16 \pm 0.35^{\mathrm{ab}}$ & $7.63 \pm 0.31^{\mathrm{b}}$ \\
Paprika & & & & \\
P3 & $4.13 \pm 0.51^{\mathrm{bc}}$ & $4.27 \pm 0.55^{\mathrm{bc}}$ & $4.89 \pm 0.98^{\mathrm{cd}}$ & $5.16 \pm 1.08^{\mathrm{cd}}$ \\
P6 & $5.97 \pm 0.28^{\mathrm{ab}}$ & $6.21 \pm 0.33^{\mathrm{ab}} 6.83 \pm 0.49^{\mathrm{abc}}$ & $7.82 \pm 0.00^{\mathrm{b}}$ \\
P12 & $6.94 \pm 1.07^{\mathrm{a}}$ & $7.34 \pm 1.34^{\mathrm{a}}$ & $8.40 \pm 1.39^{\mathrm{a}}$ & $10.00 \pm 0.72^{\mathrm{a}}$ \\
Vitamin A pure $(\mathrm{ml})$ & & & \\
A70 & $5.07 \pm 1.19^{\mathrm{abc}}$ & $5.22 \pm 1.14^{\mathrm{abc}} 6.74 \pm 0.16^{\mathrm{abc}}$ & $6.06 \pm 0.58^{\mathrm{bcd}}$ \\
A75 & $3.53 \pm 0.24^{\mathrm{c}}$ & $3.77 \pm 0.14^{\mathrm{c}}$ & $4.06 \pm 0.26^{\mathrm{d}}$ & $4.38 \pm 0.15^{\mathrm{d}}$ \\
A80 & $4.09 \pm 0.51 \mathrm{~b}^{\mathrm{c}}$ & $4.25 \pm 0.44^{\mathrm{bc}}$ & $4.43 \pm 0.51^{\mathrm{d}}$ & $4.61 \pm 0.60^{\mathrm{cd}}$ \\
Control & $5.38 \pm 0.43 \mathrm{ab}^{\mathrm{c}} 5.70 \pm 0.25^{\mathrm{abc}} 6.01 \pm 0.22^{\mathrm{bcd}}$ & $6.33 \pm 0.16^{\mathrm{bc}}$ \\
\hline
\end{tabular}

a,b,c,d,e,f, and g means in the same column different letters differ significantly at 0.05 level .

(T2,T3,T4: Tomato 20-40-60 g/Kg), (P4,P5,P6 : Paper 30-60-

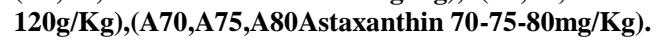

\section{REFERENCES}

A.O.A.C. (2000).Official Methods of Analysis, Associationof Official Analytical Chemists. AOAC Press, Gaithersburg, USA.

Abdelhamid, A. Salem, M.M.F. and Tolan, A.E. (2004). Evaluation of sesame meal as a dietary protein source for Nile tilapia (Oreochromis niloticus) fingerlings .J. Agric. Sci. Mansoura Univ., 29:6887-6897.

Amaninejad, P.Emtiazjoo., H. and Hosseinzadehsahafi, H. (2009). Effect of Dunaliella microalgae (Dunaliellasalina) on different immune indices (complement C3,C4 and antioxidant capacity)in rainbow trout Scientific and research jornal of marine biology. Islamic azaad university, ahvaz,pp:3-21.

Aruoma, B. Halliwell, R. Aeschbach, J. Loligers (1992). Antioxidant and pro-oxidant properties of active rosemary constituents: carnosol and carnosic acid. Food Chem Toxicol 34: 449-456.

Bjelakovic G, Nikolova D, Gluud LL, Simonetti RG, Gluud C. (2007). Mortality in randomized trials of antioxidant supplement for primary and secondary prevention: systematic review and meta-analysis. JAMA297(8):842-857.

Bjerkeng,B., T. Storebakken and S.liaaen-Jensen(2000). Response to carotenoids by rainbow trout in the sea: resporption and metabolism of dietary astaxanthin and canthaxanthin. Aquaculture, 91:153-162.

Britton G, Liaaen-jensen s, pfander H, editors . (2004). Carotenoids - handbook .Basel : Birkhauser verlag.

Britton G, Liaan-Jensen S, Pfander H , Frank HA, Young AY, Britton G, Cogdell RJ, editors. (1999). The photochemistry of carotenoids. Dordrecht: Kluwer Academic publishers.
Castell, J. D. and Tiews, K. (1980). Report of the EIFACIUNS and ICES working group on standardization of methodology in fish nutrient research. Hamburg, Federal Republic of Germany, 21-23 March (1979). EIFAC Tech, Pap. 36:24.

Chien, Y. H., Chen, I. M., Pan, C. H., \& Kurmaly, K. (1999). Oxygen depletion stress on mortality and lethal course of juvenile tiger prawn Penaeusmonodon fed high level of dietary astaxanthin. Journal of the Fisheries Society of Taiwan, 26, 85-93. Retrieved from http:// eurekamag.com/research /003/ 517/ oxygendepletionstress-mortality - lethal - juvenile - tiger - praw penaeusmonodon - fed - high - degree dietary - astaxanthin. php.

Duncan, D. B z. (1955). Multiple-range and multiple F testsBiometrics 11:1-42.

Egan, H; Kirk, RS; Sawyer, R and Pearson, D (1981). Pearson's chemical analysis of foods. 8th Edn., Churchill Livingstone. P: 537.

Elliott R. (2005). Mechanisms of genomic and nongenomic action of carotenoids Biochim Biophys Acta 1740(2):147-154

Faghani,T.Azaritakami,G.Ghiasi,M.Faghani,S.andAhma difar,A.(2009).Evaiuation of ergosan and antistreptococcus vaccine effect on hematological parameters. Journal of fisheries,pp:7.

Freyhof,J.andKottelat,M.,(2008).Alburnoidesprespensis. The IUCN RedList of Threatened Species.Version 2014.2. http:// www. iucnredlist .org (Accessed 14 June 2014).

Giovannucci E.(1999). Tomatos, tomato-based products, lycopene, and cancer; review of the epidemiologic literature. J Natl Cancer inst 91(4):317-331.

Hancz, C., I. Magyary, T. Molnar, S. Sato, P. Horn and N. Taniguchi. (2003). Evaluation of color intensity enhanced by paprika as feed additive in goldfish and koi carp using computer-assisted image analysis. Fish. Sci. 69:1158-1161.

Harpaz, S., M,Rise,S. Arad (Malis)and N.Gur,(2000). The effect of threecarotenoid sources on growth and pigmentation of juvenile freshwater crayfish cheraxquadricarinatus. Aquacult. Nutr., 4: $201-$ 208.

Hernandez LH, Teshima S, Koshio S, Ishikawa M., Tanaka Y, Alam MS. (2007). Effects of vitamin A on growth, serum anti-bacterial activity and transaminase activities in the juvenile Japanese flounder (Paralichthy solivaceus). Aquaculture 262, 444-450.

Hu CJ, Chen SM, Pan CH, Huang CH. (2006). Effects of dietary vitamin A or $\beta$-carotene concentrations on growth of juvenile hybrid tilapia, Oreochromis niloticus $\times$ O. aureus. Aquaculture, 253(1-4), 602-607.

Jeong, D.-H., An., S., Kang, H.-G., Moon, S., Han, J.-J., Park, S., Lee, H.S., An, K. and An, G. 2002. TDNA insertional mutagenesis for activation tagging in rice. Plant Physiol. 130: 1636-1644. O.I. 
Kalinowski CT, Robaina LE, Fernandez-palacios H, Schuchardt D, Izquierdo MS. (2005). Effect of different carotenoid sources and their dietary levels on red porgy (Pagrus pagrus) growth and skin color. Aquaculture, 244: 223-231.

Kavanaugh CJ, Trumbo PR, Ellwood KC. (2007). The U.S.food and Drug Administration's evidencebased review for qualified health claims: tomatoes, lycopene, and cancer.J Natl Cancer inst, 99 (14): 1074-1085.

Kirk, R. S and Sawyer, R. (1991). Pearson's composition and analysis of foods (9th ed.).UK: Longman Scientific and Technical, pp. 640, 643.

Kotkov, Z., J. Lachman, A. Hejtmnkov, and K. Hejtmnkov.(2011). Determination of antioxidant activity and antioxidant content in tomato varieties and evaluation of mutual interactions between antioxidants.LWT - Food Science and Technology, 44: 1703- 1710.

Maede,T.Hossein,K.Jalil,Z.Shayan,G.Arezo,K.and Elham,M. (2013).Study on Effect of Red Bell Pepper on Growth , Pigmentation and Blood Factors of Rainbow Trout (Oncorhynchus mykiss ). World Journal of Zoology 8(1):17-23 .

Mehrabi,Y., CRB saad and A Alimon, (2008). The effects of plant pigments on the growth and survival on rainbow trout fry until fingerling stage.UlusualAlabahkSempozyumu 14-16 EkimISPARTA, PP:24-30.

NRC, National Research council. (1993). Nutrient requirements of fish. National Academy Press, Washington D. C.USA.

Ribaya-Mercado JD,Blumberg JB, (2004). Lutein and zeaxanthin and their potential roles in disease prevention. J Am coll Nutr., 23(90006):567S$587 \mathrm{~S}$.

Richter ,N, perumal.S, and klaws,B (2003) .Evaluation of nutritional quality of Moringa leaves as an alternative protein source for Nile tilapia. Aqualalture, (217): 599-611.
Rodrigues, E.; Mariutti, L.R.B.; Chisté, R.C.; Mercadante, A.Z. (2012). Development of a novel micro-assay for evaluation of peroxyl radical scavenger capacity: Application to carotenoids and structure-activity relationship. Food Chem., doi:10.1016/j. foodchem. 2012. 06. 074.

Sajjad, M. Meysam, M. B. and Hamed, N.A. (2013). Effect of Placement Carrot (Daucus carota) and Red Pepper (Capsicum annuum) in Dietson Coloration of Jewel Cichlid (Hemichromis bimaculatus). World Journal of fish and Marine Sciences 5 (4): 445-448 .

Shimeino,S.Masumoto,T. and Hujita,T (1993). Alternative protein sources for fish meal diets of young yellowtail .Nippon suisan Gakkaishi, 59: 137-143.

SPSS (1997). Statistical package for the social sciences, Revisions 6, SPSS Inc.chicago, USA.

Strati, I.F., Oreopoulou, V. (2014). Effect of extraction parameters on the carotenoid recovery from tomato waste. Int J Food Sci Tech., 46: 23-29.

Wang YJ, Huchien Y, Hugpan C. (2006). Effects of dietary supplementation of carotenoids on survival, growth, pigmentation and antioxidant capacity of characins (Hyphessobrycallistus). Aquaculture, 261: 641-648

Yanar, Y., H. Büyükçapar, M. Yanar and M. Göcer. (2007). Effect of carotenoids from red pepper and marigold flower on pigmentation, sensory properties and fatty acid composition of rainbow trout. Food Chem., 100: 326-330.

Yew-HU ,C . Wen-Chung, S. (2005). The effect of dietary supplementation of algea and synthetic astaxanthin on body astaxanthin ,survival, growth , and low dissolved oxygen stress resistance of Kuruma prawn, Marsupenaeus japonicas Bate . Journal of Experimental Marine Biology and Ecology $318: 201-211$.

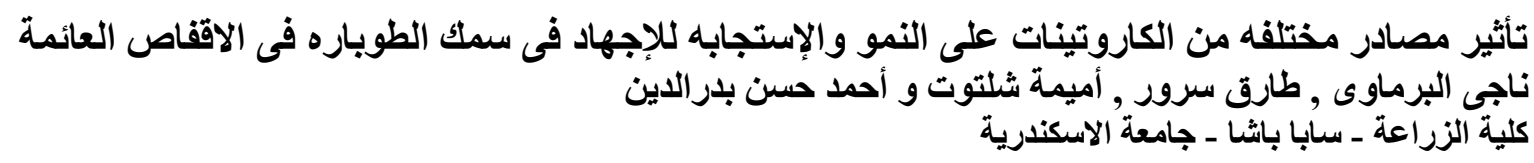

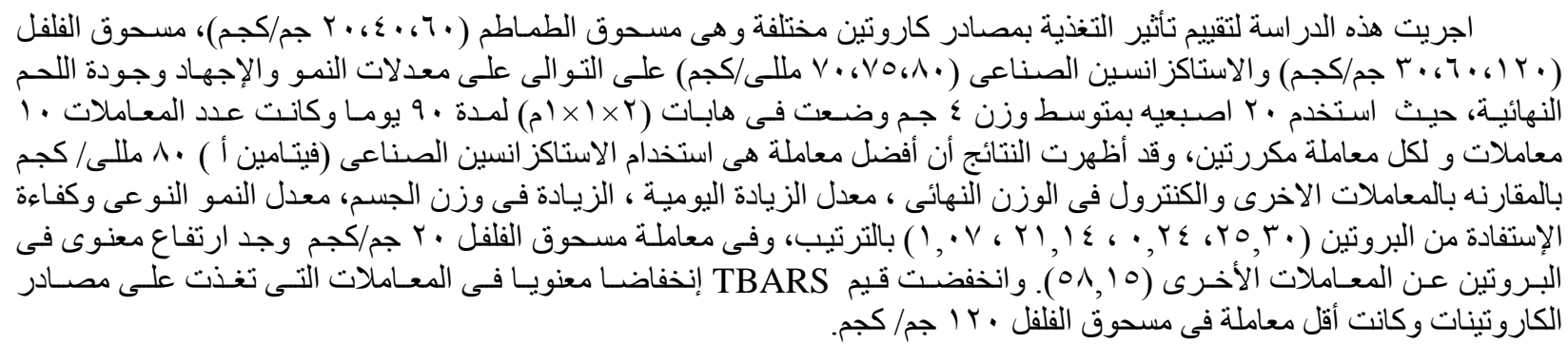

